\title{
50 years of Radiation and Environmental Biophysics: What were the hallmark papers?
}

\author{
Anna A. Friedl • Werner Rühm
}

Received: 11 March 2013/ Accepted: 11 March 2013/Published online: 27 March 2013

(C) Springer-Verlag Berlin Heidelberg 2013

You certainly have noticed that this year Radiation and Environmental Biophysics celebrates its 50-year anniversary (Rühm and Friedl 2013). This is a good opportunity to look back and identify those manuscripts in the journal that later turned out to be of scientific importance for the further developments in radiation research. Of course, the definition of hallmark papers is not as straightforward as it may appear at first glance, and different criteria may be used in that process. Each approach has its pros and cons. For example, citation rates can provide a hint on the acceptance a certain article has received in the scientific community. They depend, however, on the scientific field, and when we had a look in our citation records, we realized that most of the top-ranking papers were from a time when the emphasis of the journal was much more on biophysics than on radiation sciences. The number of full-text downloads from the REB website may be another indicator of importance, but may not adequately represent manuscripts that were published in the early phase of our journal. Furthermore, we did not want to shift all responsibility on to pure metrics.

In the end, after considering all possible options, we decided to ask our Associate Editors and our Editorial Board members to identify those papers which THEY consider hallmark. Of course, more recent papers will

\footnotetext{
A. A. Friedl ( $\square)$

Department of Radiation Oncology,

Ludwig-Maximilians-University, 80336 Munich, Germany

e-mail: RadiatEnvironBiophys@1rz.uni-muenchen.de

W. Rühm

German Research Center for Environmental Health,

Helmholtz Zentrum München, 85764 Neuherberg, Germany
}

come to mind more easily than older ones, and most scientists will not be very aware of papers that were published before their own active period. Because we believe, however, that our Associate Editors and Board members represent a fair cross-section over the scientific areas relevant for REB and because they show quite a representative mixture between younger and older scientists, we trust that their choice is a good representation of the journal's highlights of the last 50 years. As indicated in Table 1, indeed the list of nominated papers covers almost the whole 50-year period, starting with Wachsmann and Jaschke (1963), at a time when the journal was still called Biophysik, and ending with Farkas et al. (2011). While a certain bias towards more recent papers is evident, there are quite some nominations from the last century (Fig. 1). Indeed, the paper most often nominated (5 times) was Kellerer and Chmelevsky (1975): Concepts of Microdosimetry. III. Mean values of the microdosimetric distribution. The list in Table 1 also reflects the traditional emphases of this journal: radio-ecology and dosimetry, risk estimation from epidemiological studies, radiobiology, and mechanistic modelling. And it reflects a long-lasting policy of openness towards scientists from countries where publishing in international journals is not always easy.

A selection from the nominated papers is currently being made (again) available in a virtual anniversary issue of Radiation and Environmental Biophysics - thanks to our publisher house Springer who in this way wants to demonstrate appreciation of the successful 50-year story of REB. Fell free to visit our website, enjoy these historic papers, and even develop your own personal hallmark list.

As Editors-in-Chief, we want to thank our Associate Editors and Members of the Editorial Board for their formidable work. We also want to thank our authors and readers without whom this journal would not live. 
Table 1 List of nominated papers

Farkas A, Hofmann W, Balásházy I, Szoke I, Madas BG, Moustafa M (2011) Effect of site-specific bronchial radon progeny deposition on the spatial and temporal distributions of cellular responses. Radiat Environ Biophys 50:281-297

Walsh L, Kaiser JC (2011) Multi-model inference of adult and childhood leukaemia excess relative risks based on the Japanese A-bomb survivors mortality data (1950-2000). Radiat Environ Biophys. 50:21-35

Fesenko S, Fesenko E, Titov I, Karpenko E, Sanzharova N, Fonseca AG, Brown J (2010) Radionuclide transfer to marine biota species: review of Russian language studies. Radiat Environ Biophys 49:531-547

Wakeford R, Darby SC, Murphy MF (2010) Temporal trends in childhood leukaemia incidence following exposure to radioactive fallout from atmospheric nuclear weapons testing. Radiat Environ Biophys 49:213-227. Erratum in: Radiat Environ Biophys 49:503

Birchall A, Puncher M, Harrison J, Riddell A, Bailey MR, Khokryakov V, Romanov S. Plutonium worker dosimetry (2010) Radiat Environ Biophys 49:203-212

Shuryak I, Hahnfeldt P, Hlatky L, Sachs RK, Brenner DJ (2009) A new view of radiation-induced cancer: integrating short- and long-term processes. Part II: second cancer risk estimation. Radiat Environ Biophys 48:275-286 Erratum in: Radiat Environ Biophys 50:607-608

Kaiser JC, Jacob P, Blettner M, Vavilov S (2009). Screening effects in risk studies of thyroid cancer after the Chernobyl accident. Radiat Environ Biophys 48:169-179

Greubel C, Hable V, Drexler GA, Hauptner A, Dietzel S, Strickfaden H, Baur I, Krücken R, Cremer T, Dollinger G, Friedl AA (2008). Competition effect in DNA damage response. Radiat Environ Biophys 47:423-429

Ivanov VK, Chekin SY, Kashcheev VV, Maksioutov MA, Tumanov KA (2008) Risk of thyroid cancer among Chernobyl emergency workers of Russia. Radiat Environ Biophys 47:463-467

Feinendegen L, Hahnfeldt P, Schadt EE, Stumpf M, Voit EO (2008) Systems biology and its potential role in radiobiology. Radiat Environ Biophys 47:5-23

Vives i Batlle J, Balonov M, Beaugelin-Seiller K, Beresford NA, Brown J, Cheng JJ, Copplestone D, Doi M, Filistovic V, Golikov V, Horyna J, Hosseini A, Howard BJ, Jones SR, Kamboj S, Kryshev A, Nedveckaite T, Olyslaegers G, Pröhl G, Sazykina T, Ulanovsky A, Vives

Lynch S, Yankovich T, Yu C (2007) Inter-comparison of absorbed dose rates for non-human biota. Radiat Environ Biophys 46(4):349-373

Jacob P, Meckbach R, Sokolnikov M, Khokhryakov VV, Vasilenko E (2007) Lung cancer risk of Mayak workers: modelling of carcinogenesis and bystander effect. Radiat Environ Biophys 46:383-394

Prysyazhnyuk A, Gristchenko V, Fedorenko Z, Gulak L, Fuzik M, Slipenyuk K, Tirmarche M (2007) Twenty years after the Chernobyl accident: solid cancer incidence in various groups of the Ukrainian population. Radiat Environ Biophys 46:43-51

Ivanov VK, Gorski AI, Tsyb AF, Maksioutov MA, Tumanov KA, Vlasov OK (2006) Radiation-epidemiological studies of thyroid cancer incidence among children and adolescents in the Bryansk oblast of Russia after the Chernobyl accident (1991-2001 follow-up period). Radiat Environ Biophys 45:9-16

Huber T, Rühm W, Kato K, Egbert SD, Kubo F, Lazarev V, Nolte E (2005) The Hiroshima thermal-neutron discrepancy for ${ }^{36} \mathrm{Cl}$ at large distances. Part I: New (36)Cl measurements in granite samples exposed to A-bomb neutrons. Radiat Environ Biophys 44:75-86

Nolte E, Huber T, Rühm W, Kato K, Lazarev V, Schultz L (2005). The Hiroshima thermal-neutron discrepancy for ${ }^{36} \mathrm{Cl}$ at large distances. Part II: Natural in situ production as a source. Radiat Environ Biophys 44:87-96

Mokrov YG (2004) Dose assessment for the Metlino and Muslyumovo populations who lived along the Techa river from 1949 to 1954 . Radiat Environ Biophys 43:209-218

Walsh L, Rühm W, Kellerer AM (2004) Cancer risk estimates for gamma-rays with regard to organ-specific doses. Part I: All solid cancers combined. Radiat Environ Biophys 43:145-151

Mokrov YG (2004) External radiation exposure of residents living close to the Mayak facility: main sources, dose estimates, and comparison with earlier assessments. Radiat Environ Biophys 43:127-139 Erratum in: Radiat Environ Biophys 43:311

Ivanov VK, Gorski AI, Tsyb AF, Ivanov SI, Naumenko RN, Ivanova LV (2004) Solid cancer incidence among the Chernobyl emergency workers residing in Russia: estimation of radiation risks. Radiat Environ Biophys 43:35-42

Hauptner A, Dietzel S, Drexler GA, Reichart P, Krücken R, Cremer T, Friedl AA, Dollinger G (2004) Microirradiation of cells with energetic heavy ions. Radiat Environ Biophys 42:237-245

Mokrov YG (2003) Reconstruction of the radionuclide spectrum of liquid radioactive waste released into the Techa river in 1949-1951.

Radiat Environ Biophys 42:7-15

Mokrov YG (2002) A reconsideration of the external dose assessment for the Techa river population. Radiat Environ Biophys 41:303-306

Gapanovich VN, Iaroshevich RF, Shuvaeva LP, Becker SI, Nekolla EA, Kellerer AM (2001) Childhood leukemia in Belarus before and after the Chernobyl accident: continued follow-up. Radiat Environ Biophys 40:259-267

Zankl M, Wittmann A (2001) The adult male voxel model "Golem" segmented from whole-body CT patient data. Radiat Environ Biophys 40:153-162

Müller WU, Bauch T, Stüben G, Sack H, Streffer C (2001) Radiation sensitivity of lymphocytes from healthy individuals and cancer patients as measured by the comet assay. Radiat Environ Biophys 40:83-89

Heidenreich WF, Brugmans MJ, Little MP, Leenhouts HP, Paretzke HG, Morin M, Lafuma J (2000) Analysis of lung tumour risk in radonexposed rats: an intercomparison of multi-step modelling. Radiat Environ Biophys 39:253-264 
Table 1 continued

Little MP, Muirhead CR, Haylock RG, Thomas JM (1999) Relative risks of radiation-associated cancer: comparison of second cancer in therapeutically irradiated populations with the Japanese atomic bomb survivors. Radiat Environ Biophys 38:267-283

Nikjoo H, O’Neill P, Terrissol M, Goodhead DT (1999) Quantitative modelling of DNA damage using Monte Carlo track structure method. Radiat Environ Biophys 38:31-38

Khokhryakov VF, Kellerer AM, Kreisheimer M, Romanov SA (1998) Lung cancer in nuclear workers of Mayak. A comparison of numerical procedures. Radiat Environ Biophys 37:11-17

Ottolenghi A, Merzagora M, Paretzke HG (1997) DNA complex lesions induced by protons and alpha-particles: track structure characteristics determining linear energy transfer and particle type dependence. Radiat Environ Biophys 36:97-103

Kellerer AM, Nekolla E (1997) Neutron versus gamma-ray risk estimates. Inferences from the cancer incidence and mortality data in Hiroshima. Radiat Environ Biophys 36:73-83

Heidenreich WF (1996) On the parameters of the clonal expansion model. Radiat Environ Biophys 35:127-129

Frankenberg-Schwager M, Frankenberg D, Harbich R, Beckonert S (1994) Evidence against the "oxygen-in-the-track" hypothesis as an explanation for the radiobiological low oxygen enhancement ratio at high linear energy transfer radiation. Radiat Environ Biophys 33:1-8

Likhtarev IA, Gulko GM, Sobolev BG, Kairo IA, Chepurnoy NI, Pröhl G, Henrichs K (1994) Thyroid dose assessment for the Chernigov region (Ukraine): estimation based on 131I thyroid measurements and extrapolation of the results to districts without monitoring. Radiat Environ Biophys 33:149-166

Lett JT (1992) Damage to cellular DNA from particulate radiations, the efficacy of its processing and the radiosensitivity of mammalian cells. Emphasis on DNA double strand breaks and chromatin breaks. Radiat Environ Biophys 31:257-277

Makrigiorgos G, Adelstein SJ, Kassis AI (1990) Auger electron emitters: insights gained from in vitro experiments. Radiat Environ Biophys 29:75-91

Booz J, Paretzke HG, Pomplun E, Olko P (1987) Auger-electron cascades, charge potential and microdosimetry of iodine-125. Radiat Environ Biophys 26:151-162

Trott KR (1982) Experimental results and clinical implications of the four R's in fractionated radiotherapy. Radiat Environ Biophys 20:159-170

Hofmann W (1982) Cellular lung dosimetry for inhaled radon decay products as a base for radiation-induced lung cancer risk assessment. I. Calculation of mean cellular doses. Radiat Environ Biophys 20:95-112

Hofmann W (1982) Cellular lung dosimetry for inhaled radon decay products as a base for radiation-induced lung cancer risk assessment. II. Microdosimetric calculations. Radiat Environ Biophys 20:113-122

Michalowski A (1981) Effects of radiation on normal tissues: hypothetical mechanisms and limitations of in situ assays of clonogenicity. Radiat Environ Biophys 19:157-172

Kaul A, Roedler HD (1980) Radioiodine: biokinetics, mean dose and dose distribution. Radiat Environ Biophys 18:185-195

Rossi HH (1979) The role of microdosimetry in radiobiology. Radiat Environ Biophys 17:29-40

Bond VP (1979) Quantitative risk in radiation protection standards. Radiat Environ Biophys 17:1-28

Kaul A, Muth H (1978) Thorotrast kinetics and radiation dose: results from studies in thorotrast patients and from animal experiments. Radiat Environ Biophys 15:241-259

Rossi HH (1977) A proposal for revision of the quality factor. Radiat Environ Biophys 14:275-283

Jacobi W (1975) The concept of the effective dose-a proposal for the combination of organ doses. Radiat Environ Biophys 12:101-109

Kellerer AM, Chmelevsky D (1975) Concepts of microdosimetry. III. Mean values of the microdosimetric distributions. Radiat Environ Biophys 12:321-335

Kellerer AM, Chmelevsky D (1975) Concepts of microdosimetry II. Probability distributions of the microdosimetric variables. Radiat Environ Biophys 12:205-216

Kellerer AM, Chmelevsky D (1975) Concepts of microdosimetry. I. Quantities. Radiat Environ Biophys 12:61-69

Jacobi W (1973) [The lung cancer risk by inhalation of Rn-222-decay products (author's transl)]. Biophysik10:103-114. German

Jacobi W (1965) [Effect of natural radiation on the respiratory tract]. Biophysik 2:282-300. German

Oberhausen E (1963) Die Altersabhängigkeit des Kalium- und Cäsium-137-Gehaltes des Menschen. Biophysik 1:135-142

Wachsmann F., Jaschke E (1963) Tiefendosis und seitlicher Dosisabfall bei Strahlungen verschiedener Homogenität. Biophysik 1: 108-113 


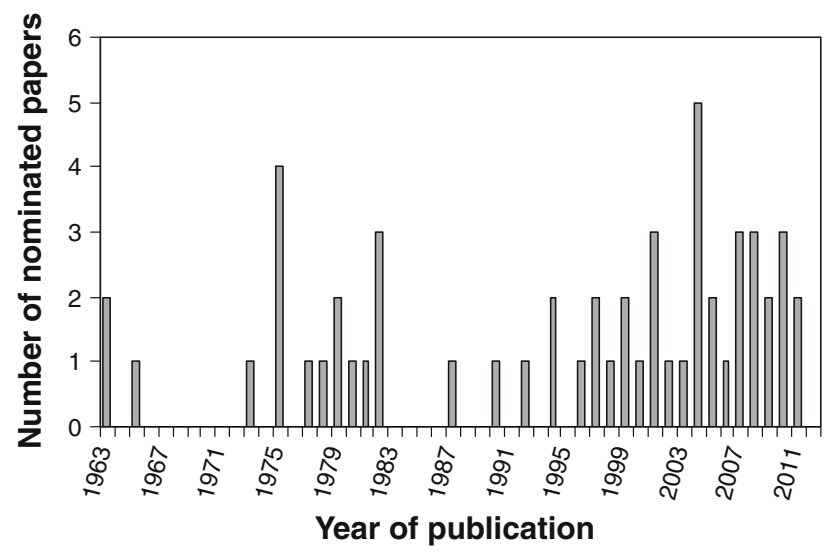

Fig. 1 Number of papers nominated as hallmark papers per publication year

\section{References}

Farkas A, Hofmann W, Balásházy I, Szoke I, Madas BG, Moustafa M (2011) Effect of site-specific bronchial radon progeny deposition on the spatial and temporal distributions of cellular responses. Radiat Environ Biophys 50:281-297

Kellerer AM, Chmelevsky D (1975) Concepts of microdosimetry. III. Mean values of the microdosimetric distributions. Radiat Environ Biophys 12:321-325

Rühm W, Friedl AA (2013) Fifty years ago. Radiat Environ Biophys 52:1-3

Wachsmann F, Jaschke E (1963) Tiefendosis und seitlicher Dosisabfall bei Strahlungen verschiedener Homogenität. Biophysik $1: 108-113$ 